\title{
Introduced Marine Species in the Haida Gwaii (Queen Charlotte Islands) Region, British Columbia
}

\author{
N. A. SLOAN and P. M. BARTIER \\ Parks Canada, Gwaii Haanas National Park Reserve and Haida Heritage Site, P.O. Box 37, Queen Charlotte, British Columbia, \\ V0T 1S0 Canada
}

Sloan, N. A., and P. M. Bartier. 2004. Introduced marine species in the Haida Gwaii (Queen Charlotte Islands) region, British Columbia. Canadian Field-Naturalist 118(1): 77-84.

This historical review of a marine area's introduced species was facilitated by geo-referenced marine species inventories of the Haida Gwaii (Queen Charlotte Islands) region. One plant, 14 invertebrate, and two fish introduced species have been recorded since the early $20^{\text {th }}$ century from the marine waters around Haida Gwaii. Records of species occurrences are listed and mapped, and modes of introduction are discussed. It will be important to continue documenting areas' introduced species locations to track the progress of invasions that could affect local marine ecosystem well-being.

Key Words: introduced species, marine, Haida Gwaii, Queen Charlotte Islands, British Columbia.

"... the control of alien marine species is in its infancy." (Bax et al. 2001)

Introduced (non-indigenous) marine species are of global concern (Bax et al. 2001). The dynamism and connectivity of marine ecosystems, mariculture and shipping facilitate species' introductions. The introduction of some species may be followed by rapid local dispersal of propagules and appreciable ecological consequences (Grosholz 2002). Introduced species knowledge is more developed for land and freshwater than for marine ecosystems (Ruiz et al. 2000; Simberloff 2000; Bax et al. 2001).

Carl and Guiguet (1958) were the first to broadly document species introductions in Pacific Canada. Current awareness of the problem is growing in the region, and Levings et al. (2002) have reviewed introduced marine species found in the Strait of Georgia, southern British Columbia.

Using the 30 introduced mollusks along the Pacific coast of North America as an example, Carlton (1992) reported the main modes of introduction as: (1) associated with introduced Japanese and Atlantic oysters imported for mariculture (approximately 27 species), (2) via vessel hull fouling and organisms living in wood, and (3) from overseas ships' ballast water releases. More recently, Chapman et al. (2003) reported that along the U.S. Pacific coast, 24 of the 37 marine and estuarine bivalve species commercially available as seafood are alien species.

We report on the documented presence of introduced marine plants, invertebrates and fishes in the Haida Gwaii (Queen Charlotte Islands) region of northern British Columbia. No introduced marine birds or mammals have been recorded. The plant and invertebrate records, gleaned from the literature and museum collections, are archived in the geographic information system (GIS) databases of Gwaii Haanas National Park Reserve and Haida Heritage Site (Sloan and Bartier
2000; Sloan et al. 2001). We excluded introduced species whose total geographic range encompasses the Haida Gwaii region, although, of course, their presence could be inferred. An example is the amphipod Corophium acherusicum from Asia and now known from the northern mainland British Columbia coast (Bousfield and Hoover 1997). The American Shad (Alosa sapidissima) have long been known from the whole northeast Pacific (Welander 1940), but only recently from Haida Gwaii waters (Workman et al. 1996). Atlantic salmon (Salmo salar) observations were from the Atlantic salmon Watch Program web site: http://www.pac.dfo-mpo. gc.ca/sci/aqua/ASWP_e.htm. The fish records are not yet in our database.

\section{Results and Discussion}

For Haida Gwaii, accidental (or active) introductions of one plant, 14 invertebrate, and two fish species associated with fishery or mariculture development are summarized in Table 1 and illustrated in Figures 1 and 2. Likely some of these species have spread northward to Haida Gwaii from the more developed southern mainland British Columbia and U.S. coasts where they first became established. There have been introductions of species to British Columbia targeted for mariculture, such as Pacific Oyster (Crassostrea gigas) from Japan, plus their attached associates (Quayle 1988) or parasites (Bower et al. 1994). For example, the seaweed Sargassum muticum is now ubiquitous coast-wide, including Haida Gwaii (Figure 1). It was accidentally introduced into southern British Columbia in the early $20^{\text {th }}$ century attached to Pacific oysters. Another example of collateral introduction in British Columbia is the parasitic copepod Mytilicola orientalis, likely introduced via Pacific Oyster stock and now widely infesting Native Littleneck Clams (Protothaca staminea) and Butter Clams (Saxidomus giganteus) in southern British Columbia (Bower et al. 1994). 


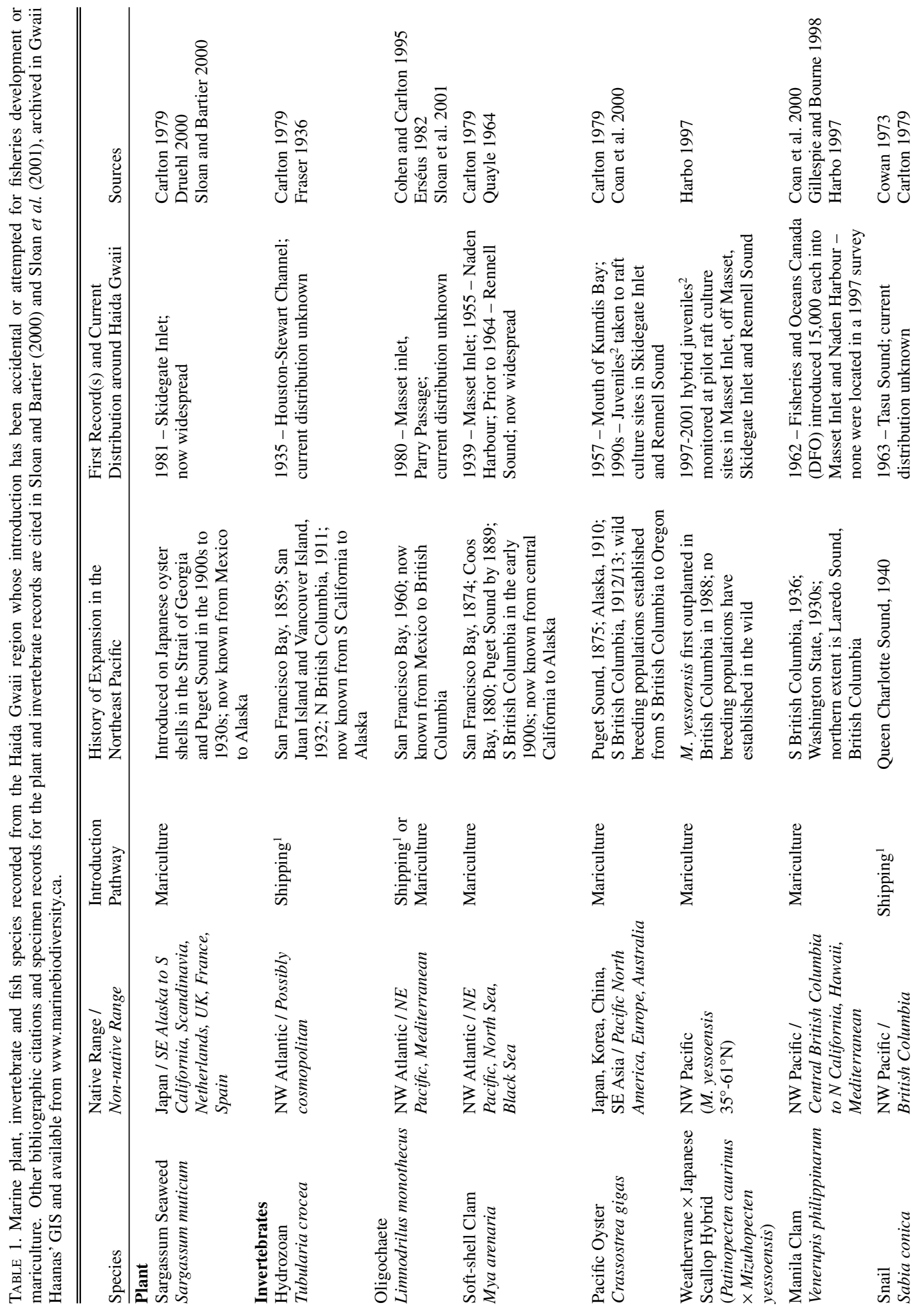




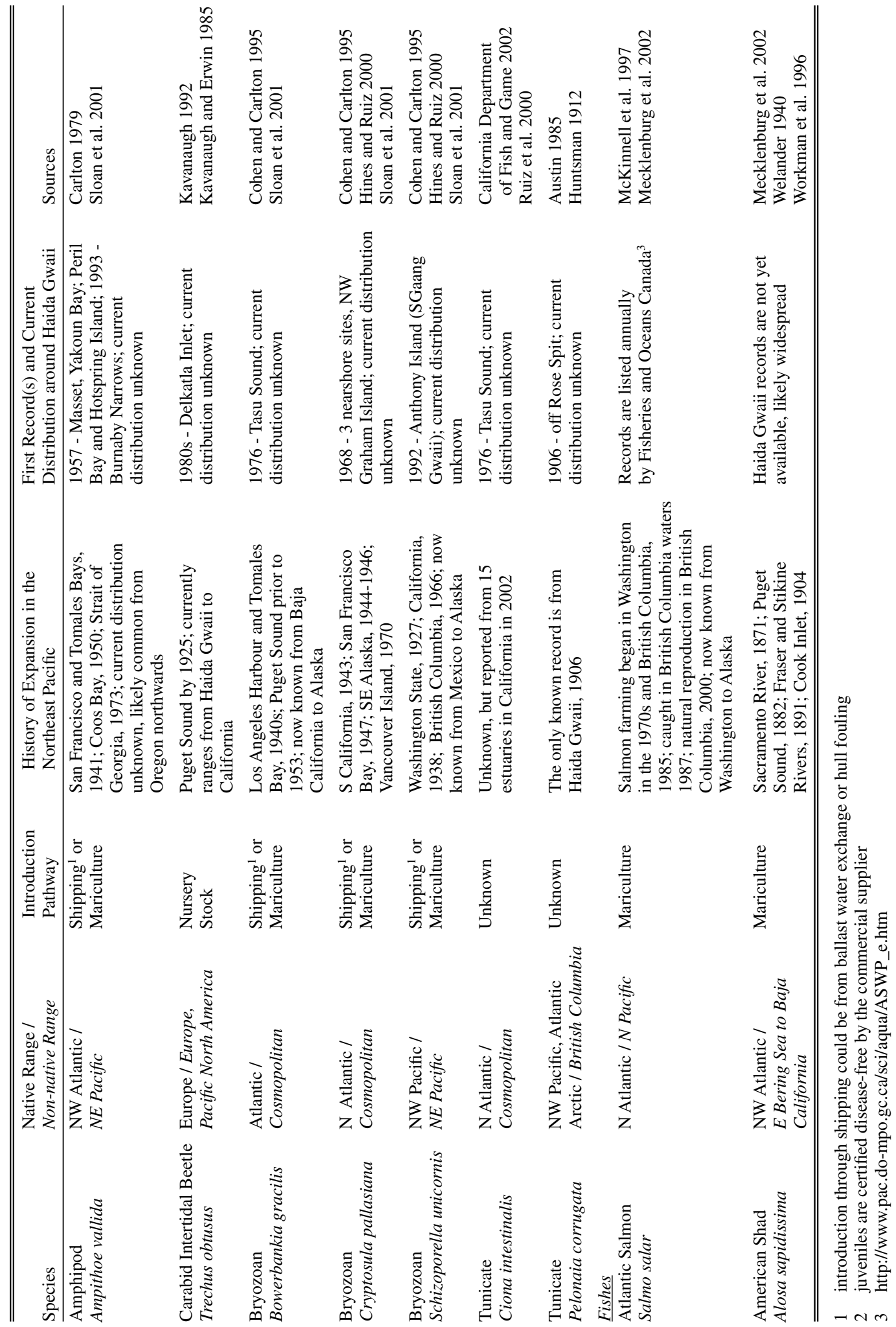




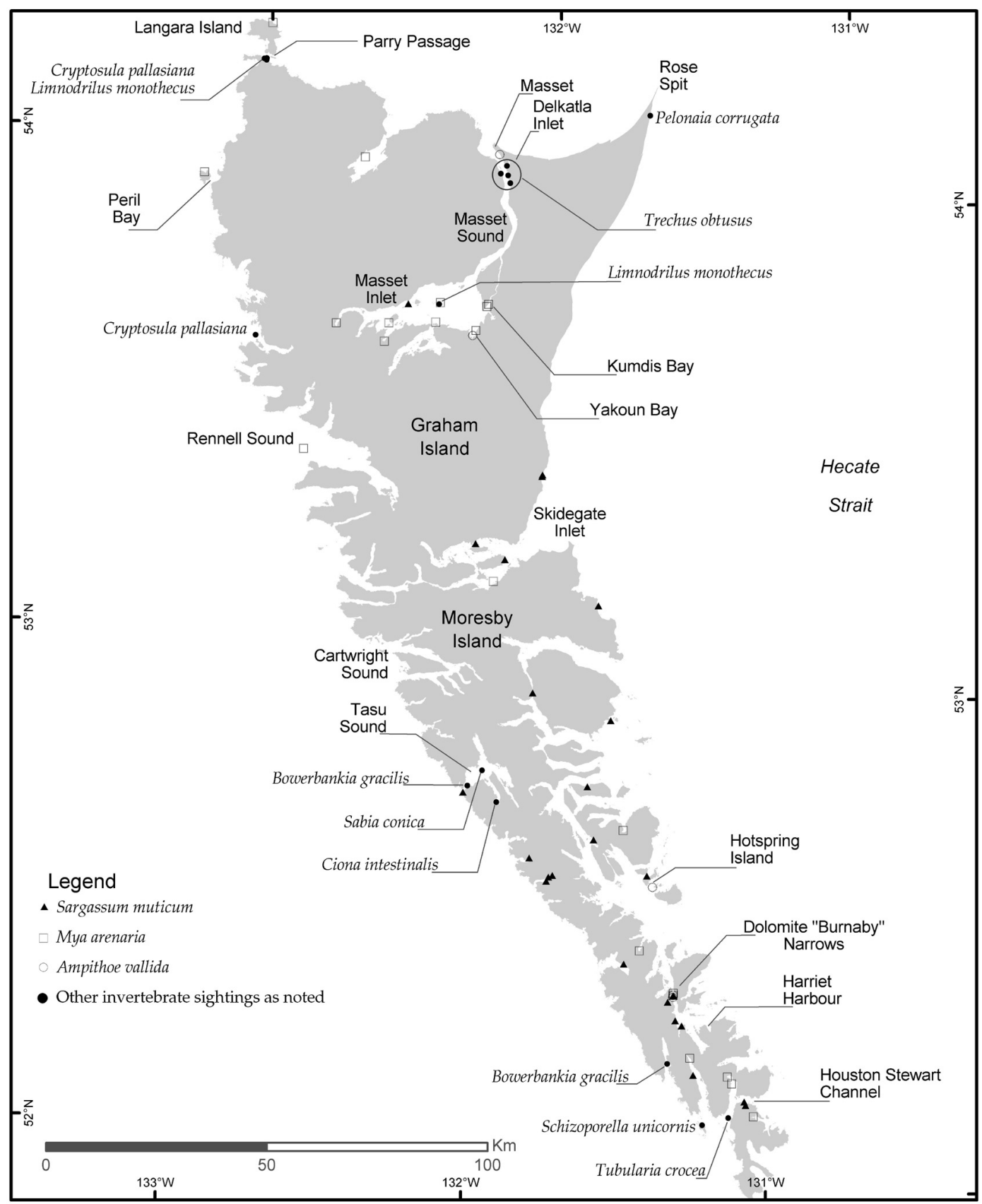

FIGURE 1. Map of Haida Gwaii showing locations mentioned in the text and collection sites of introduced marine plant and invertebrate species, based on data from Sloan and Bartier (2000) and Sloan et al. (2001).

\section{Mariculture-associated Introductions}

In 1977, concern over introduced aquatic species issues stimulated establishment of the federal-provincial Fish Transplant Committee (recently renamed Introductions and Transfers Committee - ITC) under mandates from the federal Fisheries Act and the British Columbia Fisheries Act and British Columbia Wildlife Act (BC 1990). The ITC evaluates potential risks to the environment associated with introductions or transfers of either finfish or invertebrates ("shellfish") 


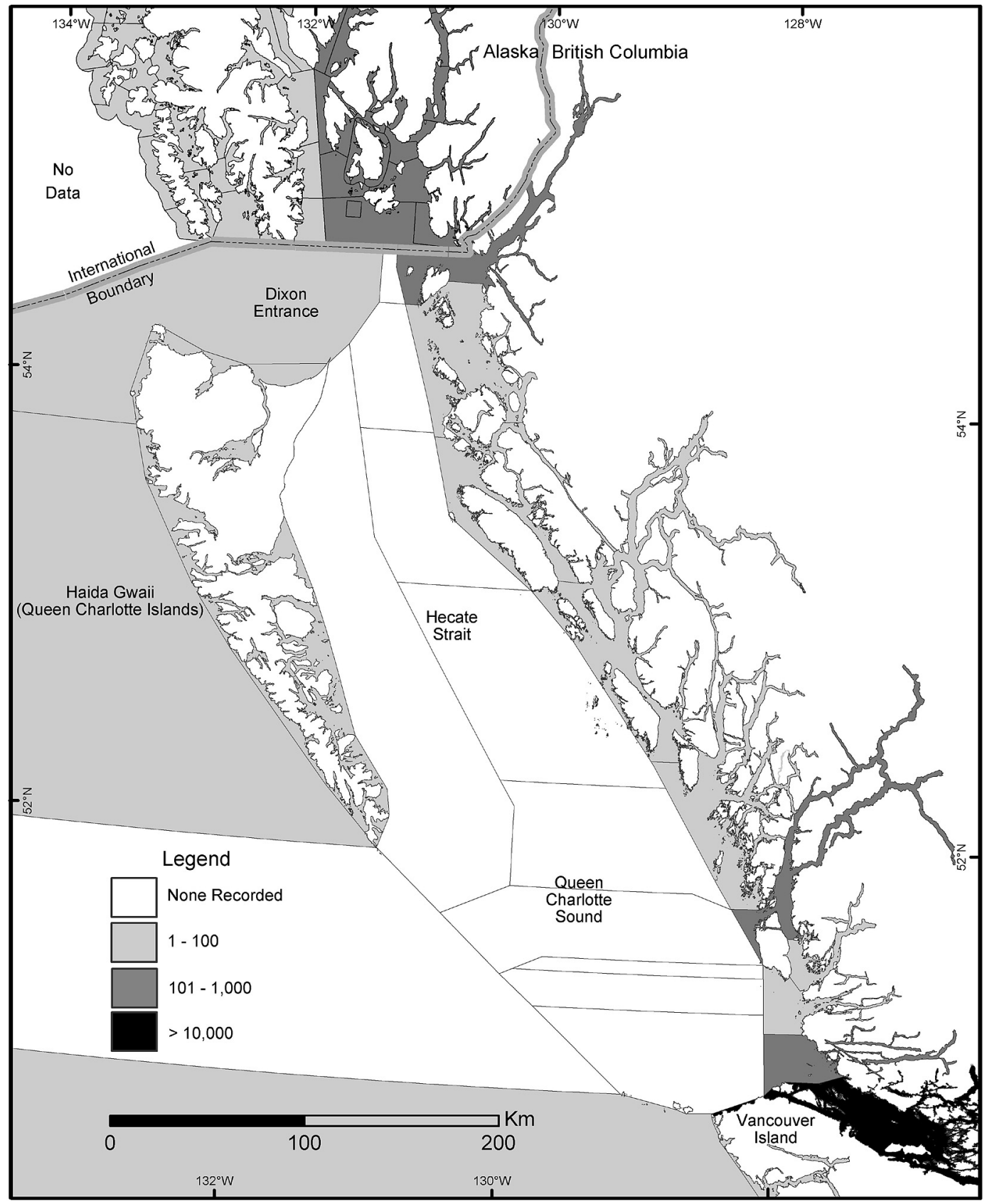

FIGURE 2. Map of the northern British Columbia and southeast Alaska regions showing the density of Atlantic salmon observations. All data are from Fisheries and Oceans Canada's Atlantic Salmon Watch Program: http://www.pac.dfo-mpo.gc. ca/sci/aqua/ASWP_e.htm. [accessed May, 2004]. British Columbia data are from 1987 to 2002 and partitioned according to Pacific Fishery Management Areas, and the Alaska data are from 1990 to 2002 and partitioned according to the Alaska Department of Fish and Game Area Polygons.

into British Columbia marine or freshwaters. Besides the species themselves and their attached associates, there is the risk of introducing diseases, parasites or genetic material into native species. Further, there are concerns over potential ecological displacement of native species. The ITC issues licences to introduce 
aquatic species into British Columbia or to transfer species between domestic water bodies.

Shellfish mariculture remains a potential avenue of species introduction to Haida Gwaii. A Masset-based group has investigated the potential for local shellfish mariculture for coastal community economic development. Leased culture operations in Skidegate Inlet and Rennell Sound remain active for Pacific Oyster culture. These operations are unlikely a threat of introducing oysters as local waters are too cold for oyster breeding although they are suitable for growth of certified disease-free juveniles (spat) from culture in southern British Columbia. However, local waters may not be too cold for oysters' parasites or other associated species. From 1997 to 2001, pilot raft culture sites were tested to grow certified disease-free Weathervane Scallop (Patinopecten sp.) hybrid (native $\times$ Japanese) spat (B. Mark, Masset, personal communication). Only the Rennell Sound site remains active for scallop culture (R. Lozon, Queen Charlotte City, personal communication). The potential for species introduction is likely low, because no successful settlement of hybrid Weathervane Scallops has occurred in British Columbia in the last decade (Island Scallops Ltd., Qualicum Beach, personal communication).

\section{Ships' Ballast Water}

Gauthier and Steel (1998) reported that Canada was receiving approximately 52 million tonnes of ballast water from foreign shipping annually with little protective policy or regulation. Indeed, the major vector of introductions to Pacific North America has been from shipping (Ruiz et al. 2000). Concerning Pacific Canada, Levings (1999) mentioned the Canadian Ballast Water Management Guidelines issued by Transport Canada in 2000 with an Annex (II) for the Pacific coast aimed at preventing introduction of non-indigenous aquatic organisms (http://www.tc.gc.ca/Marine Safety/). These Guidelines will become Regulations under the Canada Shipping Act.

The Vancouver Port Authority has had a mandatory ballast water program since 1997. It is based on the assumption that mid-ocean ballast water exchange, with water containing pelagic species not likely adapted to coastal conditions, decreases likelihood of introducing viable species into port waters (Levings et al. 2004). Port authorities are now finding, however, that such exchange criteria are only partially effective (C. Levings, Fisheries and Oceans Canada (DFO), personal communication). Other British Columbia ports invoking ballast water management are Nanaimo and New Westminster. The north coast of British Columbia, with an active deep-water international port in Prince Rupert, however, has no ballast water program. Further, Levings et al. (2004) express concern about "intracoastal" transport. For example, from Haida Gwaii there is on-going barge and self-dumping log barge traffic with southern British Columbia and there has been relatively recent international vessel traffic for mine ore concentrates from Tasu Sound (mine closed 1973) and Harriet Harbour (mine closed 1968).

The ecological effects of introduced species such as invertebrates on the Pacific coast are poorly studied (Carlton 1992). It is sobering to reflect that, once introduced, marine species may be difficult to control and their ecosystem consequences may be damaging (Simberloff 2000; Grosholz 2002). An example is the European Green Crab, Carcinus maenas, introduced to the San Francisco Bay area in 1989. The Green Crab has since been recorded from Esperanza Inlet on the northwest coast of Vancouver Island (Jamieson et al. 2002). As active predators, Green Crabs could affect British Columbia intertidal fauna, as they have in California (Grosholz 2000).

Times and attitudes have changed about introductions of marine species. In the 1980s, DFO discussed introduction of the large, predatory Atlantic lobster (Homarus americanus) around Haida Gwaii. Barber (1983) concluded that up to $7700 \mathrm{~km}^{2}$ of Hecate Strait area south of Skidegate Inlet, as well as Masset Inlet, were suitable for lobster introduction. Now, such initiatives are contrary to agency mandates for sustainable, ecosystem-based management.

Among introduced marine species, Atlantic Salmon (Salmo salar) currently has the highest ecosystem and socio-political profile in British Columbia (Gross 1998; Volpe et al. 2001). Important issues include escapement and persistence in river systems facilitating competition for spawning habitat with native salmonids. Further, the threat of continuing introductions helps animate the vigorous debate over expansion of salmon farming in British Columbia. Although Atlantic Salmon have been reported from Haida Gwaii coastal waters, there are no salmon farms in Haida Gwaii, and there are no records at this time of Atlantic salmon from within Haida Gwaii rivers and streams (V. Fradette, DFO, personal communication).

This overview of a marine region's introduced species was facilitated through marine species inventories from the historical literature of the Haida Gwaii region. We do not claim that it is complete, but it is a start. It will be important to continue documenting introduced species reports to track the progress of introductions that could affect local marine ecosystem well-being.

\section{Acknowledgments}

We thank C. D. Levings of Fisheries and Oceans Canada (DFO) for reviewing an early draft and G. E. Gillespie (DFO) for information on fishes.

\section{Literature Cited}

Austin, W. C. 1985. An annotated checklist of marine invertebrates in the cold temperate northeast Pacific. Khoyatan Marine Laboratory, Cowichan Bay, British Columbia. 3 volumes. 682 pages. 
Barber, F. G. 1983. Lobster transplant to Masset Inlet. Canadian Technical Report of Fisheries and Aquatic Sciences 1181. 6 pages.

Bax, N., J. T. Carlton, A. Mathews-Amos, R. L. Haedrich, F. G. Howarth, J. E. Purcell, A. Rieser, and A. Gray. 2001. The control of biological invasions in the world's oceans. Conservation Biology 15: 1234-1246.

BC (British Columbia Ministry of Agriculture, Fisheries and Food). 1990. Federal and Provincial Transplant Regulations. Aquaculture Factsheet Bulletin (Aquaculture and Commercial Fisheries Branch) 8-1. 3 pages.

Bousfield, E. L., and P. M. Hoover. 1997. The amphipod superfamily Corophioidea on the Pacific coast of North America. Part V. Family Corophidae. Corophiinea, new subfamily. Systematics and distributional ecology. Amphipacifica 2(3): 67-139.

Bower, S. M., S. E. McGladdery, and I. M. Price. 1994. Synopsis of infectious diseases and parasites of commercially exploited shellfish. Annual Review of Fish Diseases 4: 1-199.

California Department of Fish and Game. 2002. A survey of non-indigenous aquatic species in the coastal and estuarine waters of California. Office of Spill Prevention and Response. [http://www.dfg.ca.gov/ospr/index.html]

Carl, G. C., and C. J. Guiguet. 1958. Alien animals in British Columbia. British Columbia Provincial Museum Handbook 14. 94 pages.

Carlton, J. T. 1979. History, biogeography, and ecology of the introduced marine and estuarine invertebrates of the Pacific coast of North America. Unpublished Ph.D. thesis, University of California, Davis, California. 904 pages.

Carlton, J. T. 1992. Introduced marine and estuarine mollusks of North America: an end-of-century perspective. Journal of Shellfish Research 11: 489-505.

Chapman, J. W., T. W. Miller, and E. V. Coan. 2003. Live seafood species as recipes for invasion. Conservation Biology 17: 1386-1395.

Coan, E. V., P. V. Scott, and F. R. Bernard. 2000. Bivalve seashells of western North America: marine bivalve mollusks from Arctic Alaska to Baja California. Santa Barbara Museum of Natural History Monographs 2. 764 pages.

Cohen, A. N., and J. T. Carlton 1995. Nonindigenous aquatic species in a United States estuary: a case study of the biological invasions of the San Francisco Bay and Delta. United States Fish and Wildlife Service, Washington, D.C. and National Sea Grant College Program, Connecticut Sea Grant, Groton. National Technical Information Service Report PB96-166-525. Springfield, Virginia. 246 pages.

Cowan, I. M. 1973. Sabia conica (Schumacher) on the Pacific coast of North America. Veliger 16: 290

Druehl, L. D. 2000. Pacific seaweeds a guide to common seaweeds of the west coast. Harbour Publishing, Madeira Park, British Columbia.

Erséus, C. 1982. Taxonomic revision of the marine genus Limnodriloides (Oligochaeta: Tubificidae). Verhandlungen des Naturwissenschaftlichen Vereins in Hamburg (NF) 25: 207-277.

Fraser, C. M. 1936. Hydroid distribution in the vicinity of the Queen Charlotte Islands. Canadian Field-Naturalist 50: 122-126.

Gauthier, D., and D. A. Steel. 1998. A synopsis of the Canadian situation regarding ship-transported ballast water. ICES (International Council for the Exploration of the Sea) Cooperative Research Report 224: 91-101.
Gillespie, G. E., and N. F. Bourne. 1998. Exploratory intertidal clam surveys in British Columbia - 1997. Canadian Manuscript Report of Fisheries and Aquatic Sciences 2465. 43 pages.

Grosholz, E. D. 2000. The impacts of a nonindigenous marine predator in a California bay. Ecology 81: 1206-1224.

Grosholz, E. D. 2002. Ecological and evolutionary consequences of coastal invasions. Trends in Ecology and Evolution 17: 22-27.

Gross, M. R. 1998. One species with two biologies: Atlantic salmon (Salmo salar) in the wild and in aquaculture. Canadian Journal of Fisheries and Aquatic Sciences 55 (Supplement 1): 131-144.

Harbo, R. M. 1997. Shells and shellfish of the Pacific Northwest: a field guide. Harbour Publishing, Madeira Park, British Columbia.

Hines, A. H., and G. M. Ruiz. 2000. Biological invasions of cold-water coastal ecosystems: ballast-mediated introductions in Port Valdez/Prince William Sound, Alaska. Regional Citizens' Advisory Council of Prince William Sound, Valdez, Alaska. 340 pages.

Huntsman, A. G. 1912. Holosomatous ascidians from the coast of western Canada. Contributions to Canadian Biology 1906-1910:103-185.

Jamieson, G. S., M. G. G. Foreman, J. Y. Cherniawsky, and C. D. Levings. 2002. European green crab (Carcinus maenas) dispersal: the Pacific experience. Pages 561-575 in Crabs in cold water regions: biology, economics and management. Alaska Sea Grant College Program AKSG-02-01.

Kavanaugh, D. H. 1992. Carabid beetles (Insecta: Coleoptera: Carabidae) of the Queen Charlotte Islands, British Columbia. Memoirs of the California Academy of Sciences 16: 113 pages.

Kavanaugh, D. H., and T. L. Erwin. 1985. Trechus obtusus Erichson (Coleoptera: Carabidae), a European ground beetle, on the Pacific coast of North America: its distribution, introduction, and spread. Pan-Pacific Entomologist 61: 170-179.

Levings, C. D. 1999. Review of current practises to reduce the risk of introducing non-indigenous species into Pacific region via ballast water. Canadian Stock Assessment Secretariat Research Document 99/211. 13 pages.

Levings, C. D., J. R. Cordell, S. Ong, and G. E. Piercey. 2004. The origin and identity of invertebrate organisms being transported to Canada's Pacific coast by ballast water. Canadian Journal of Fisheries and Aquatic Sciences 61: 1-11.

Levings, C. D., D. Kieser, G. S. Jamieson, and S. Dudas. 2002. Marine and estuarine alien species in the Strait of Georgia, British Columbia. Pages 111-131 in Alien invaders in Canada's waters, wetlands, and forests. Edited by R. Claudia, P. Nantel and E. Muckle-Jeffs. Natural Resources Canada, Canadian Forest Service, Ottawa.

McKinnell, S., A. J. Thompson, E. A. Black, B. L. Wing, C. M. Guthrie III, J. F. Koerner, and J. H. Helle. 1997. Atlantic salmon in the North Pacific. Aquaculture Research 28: 145-157.

Mecklenburg, C. W., T. A. Mecklenburg, and L. K. Thorsteinson. 2002. Fishes of Alaska. American Fisheries Society, Bethesda, Maryland. 1037 pages.

Quayle, D. B. 1964. Distribution of introduced marine mollusca in British Columbia waters. Journal of the Fisheries Research Board of Canada 21: 1155-1181. 
Quayle, D. B. 1988. Pacific oyster culture in British Columbia. Canadian Bulletin of Fisheries and Aquatic Sciences 218. 241 pages.

Ruiz, G. M., P. W. Fofonoff, J. T. Carlton, M. J. Wonham, and A. H. Hines. 2000. Invasion of coastal marine communities in North America: apparent patterns, processes, and biases. Annual Review of Ecology and Systematics 31: 481-531.

Simberloff, D. 2000. No reserve is an island: marine reserves and nonindigenous species. Bulletin of Marine Science 66: 567-580.

Sloan, N. A., and P. M. Bartier. 2000. Living marine legacy of Gwaii Haanas. I. Marine plant baseline to 1999 and plant-related management issues. Parks Canada Technical Reports in Ecosystem Science 27. 104 pages.

Sloan, N. A., P. M. Bartier, and W. C. Austin. 2001. Living marine legacy of Gwaii Haanas. II. Marine invertebrate baseline to 2000 and invertebrate-related management is- sues. Parks Canada Technical Reports in Ecosystem Science 35.331 pages.

Volpe, J. P., B. R. Anholt, and B. W. Glickman. 2001. Competition among juvenile Atlantic salmon (Salmo salar) and steelhead (Oncorhynchus mykiss): relevance to invasion potential in British Columbia. Canadian Journal of Fisheries and Aquatic Sciences 58: 197-207.

Welander, A. D. 1940. Notes on the dissemination of shad, Alosa sapidissima (Wilson), along the Pacific coast of North America. Copeia 1940: 221-223.

Workman, G. D., J. Fargo, B. Beall, K. L. Yamanaka, and V. Haist. 1996. R/V W.E. Ricker assemblage survey of Hecate Strait, May 23-June 9, 1995. Canadian Data Report of Fisheries and Aquatic Sciences 974. 94 pages.

Received 27 December 2002

Accepted 11 June 2004 


\section{Erratum 118(1): 80}

Sloan, N. A., and P. M. Garier. 2004. Introduced marine species in the Haida Gwaii (Queen Charlotte Islands) Region, British Columbia. Canadian Field-Naturalist 118(1): 77-84.

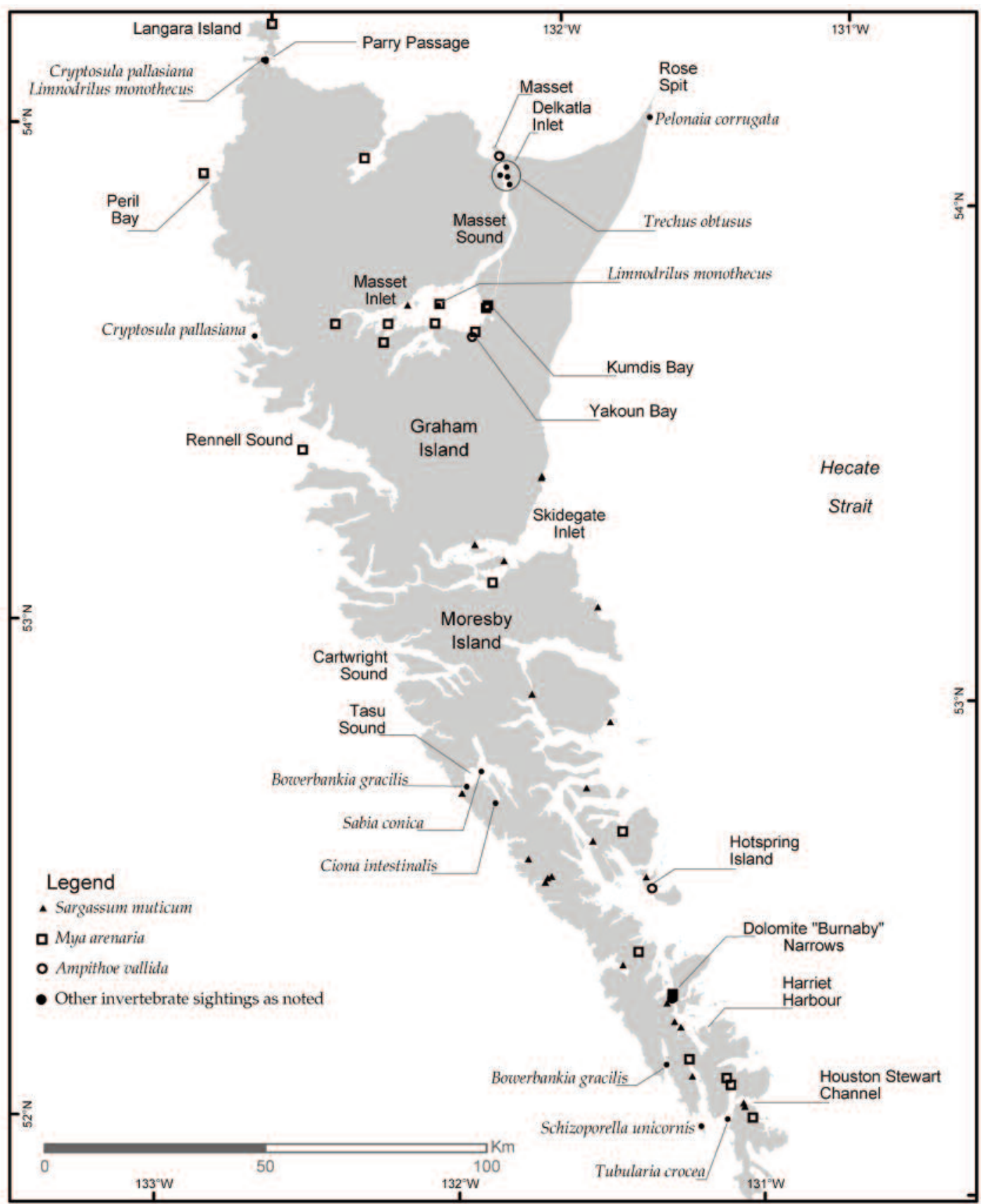

FIGURE 1. Map of Haida Gwaii showing locations mentioned in the text and collection sites of introduced marine plant and invertebrate species, based on data from Sloan and Bartier (2000) and Sloan et al. (2001). 